\title{
Forebygging av selvmord i Forsvaret gjennom 50 år
}

Ved Elisabeth N æss

Forsvaret har vaert aktive og vist interesse for selumordsproblematikken gjennom mer enn 50 år. Allerede så tidlig som i 1952 ble alle militaere enheter pålagt å registrere selvmord og selumordsforsøk blant personellet. Utredninger og undersøkelser i Forsvaret på 1970-90-tallet viste omtrent samme økning i selvmordsraten som i det norske samfunnet for øvrig og resulterte blant annet $i$ et selumordsforebyggende program med undervisningstiltak rettet mot både vernepliktig og øurig personell i Forsvaret. Innfallsvinkelen for Forsvaret var at det måtte betraktes som et klart forvaltningsansvar å ha en strategi i forhold til den økende selvmordsproblematikken. Nedenfor redegjøres det for hvordan det selvmordsforebyggende arbeidet har utviklet seg i Forsvaret, og hvilke undervisningsopplegg som tilbys de ulike personellgruppene.

Forsvaret påla så tidlig som i 1952 alle militære enheter å registrere selvmord og selvmordsforsøk blant personellet. Registreringsarbeidet man utførte den gang, var forut for sin tid sammenliknet med den sivile forvaltning og det relativt beskjedne omfanget av sel vmord og selvmordsforsøk i N orge. Dette arbeidet la et godt grunnlag for forskning vedrøren de omfang og årsaker av så vel selvmord som selvmordsforsøk blant militært personell. M an fulgte særlig godt med i statistikkene over de vernepliktige mannskapene. Det vises i denne sammenheng blant annet til Bull Engelstads undersøkelse fra 1968 om hyppigheten av selvmord i sammenliknbare grupper av unge menn i og utenfor Forsvaret, som viste at hyppigheten av selvmord var noenlunde lik i disse gruppene.

I løpet av 1970- og 80-årene erfarte $\mathrm{N}$ orge en kraftig stigning av selvmordsraten i befolkningen, særlig steg selvmordsraten sterkt blant unge menn. Denne $ø$ øningen ble også reflektert i gruppen av vernepliktig personell som vist i Karsten $\mathrm{H}$ yttens undersøkelse fra 1985. H ytten konkluderte blant annet med at selvmordstallene blant vernepliktige i perioden

1977 til 1984 viste en firedobling i forhold til tidligere perioder.

I 1991 ble det med bakgrunn i en undersøkelse av Lars M ehlum om årsaksforhold og utløsende faktorer i relasjon til selvmordshandlinger, laget et grundig fundament for utvikling av selvmordsforebyggende tiltak blant militært personell.

Resultatene i undersøkelsen viste blant annet at rekruttene var mest utsatt, samt at soldaten es bakgrunn, tjen esteforhold og reaksjoner klassifisert som tilpasningsforstyrrelser i mange tilfeller var utløsende faktorer. Det ble også fokusert på viktigheten av forebyggende arbeid for å kunne fange opp soldaten ved tidlige signaler på

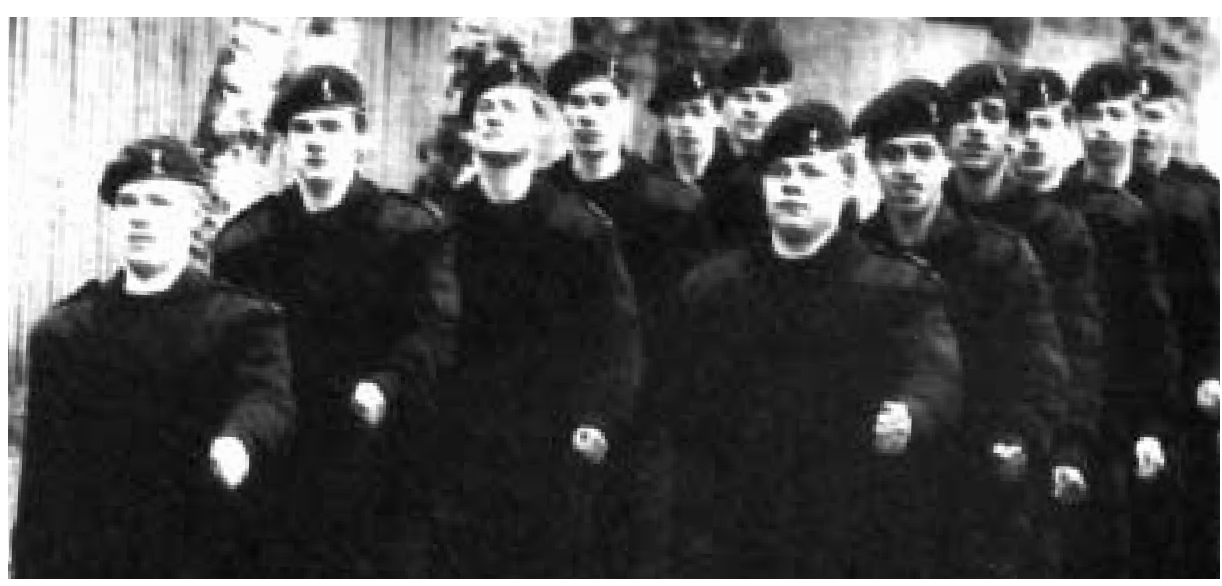

suicidalitet og på behovet for økt kunnskap om dette både blant helsepersonell og ikke minst blant befal et og soldatene selv.

De publiserte funn resulterte i at Forsvaret i 1991 nedsatte en tverrfaglig ekspertgruppe ( $M$ ehlum-utvalget) som fikk i mandat å sammenstille og evaluere den viten og de erfaringer som allerede eksisterte om selvmord og selvmordsforsøk blant personell i Forsvaret. U t fra dette grunnlag skulle ekspertgruppen utvikle forslag til konkrete selvmordsforebyggen de tiltak. $\mathrm{M}$ ålgruppen var alt personell i Forsvaret, men med hovedfokus på de vernepliktige mannskaper.

A rbeidet i utval get ble avsluttet i 1993 og resulterte i en omfattende utredning "Forebyggelse av selvmord i Forsvaret ". Innfallsvinkelen for Forsvaret var at det måtte betraktes som et klart forvaltningsansvar å ha en strategi i forhold til den økende selvmordsproblematikken. Dette ble gjort gjelden de for alle grupper, men kanskje i særlig grad ovenfor det vernepliktige personellet som er pålagt en tjeneste som ofte medfører belastninger de ikke så lett kan fritas for. For vernepliktige er tjenesten mer enn en jobb - det er en totalsituasjon på godt og vondt ( $M$ ehlum et al., 1993)
Førstegangstjenesten er Forsvarets møte med ca $60 \%$ av den mannlige befolkningen (og et økende antall kvinner), noe som gir en unik mulighet til å tilføre store grupper av ungdom kunnskaper om sel vmordsproblemene generelt, om al ternative mestringsstrategier og om hvilke former for hjelp som kan tilbys. H ovedformålet med de selvmordsforebyggen de tiltakene må være å hindre soldater i å ta livet av seg. M en det å øke unge menneskers mestringsevne generelt kan også ses som et viktig mål som både vil tjene totalforsvarshensyn og mer allmenne etiske hensyn.

Videre fant ekspertgruppen det nødvendig å satse på rene forebyggende tiltak på alle nivåer, noe som innebærer å iverksette primær,- sekundær- og tertiærforebyggen de tiltak.

Primærforebygging dreier seg om å påvirke mål gruppens generelle levevilkår, slik at færrest mulig får problemer og beveger seg over i risikogrupper.

Sekundærforebygging betyr i denne sammenheng å identifisere risikogrupper og iverksette tiltak for å hindre at disse lider helseskade, eller i dette tilfellet gjør selvmord eller selvmordsforsøk. 


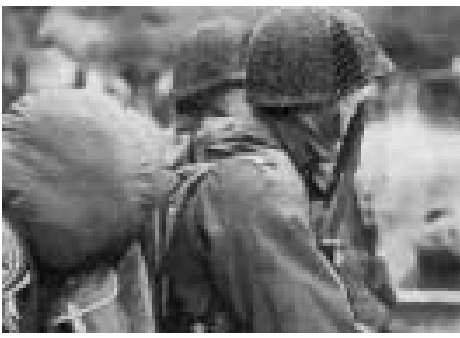

Tertiærforebygging dreier seg om å iverksette tiltak i behandling og rehabilitering av personer som har gjort selvmordsforsøk for å hindre ytterligere forverring av tilstanden eller gjentakel se av atferden, evt. med dødelig utgang.

U tredningen fra ekspertgruppen har siden dannet grunnlaget for mye av det videre selvmordsforebyggen de arbeid i Forsvaret og representerer et helhetlig forebyggingsprogram. Så vidt vi vet, har ingen andre europeiske land eller N ATO land til nå utviklet slike helhetlige forebyggingsprogrammer i en militær kontekst, til tross for at selvmordsproblematikken blant militært personell er velkjent og dokumentert i mange land. (M ehlum 1999)

"Direktiv for utdanning i selvmordsforebyggen de arbeid i Forsvaret" ble iverksatt i 1995 og er fremdeles gjeldende retningslinjer for alt selvmordsforebyggende arbeid i Forsvaret. For å redusere antall selvmordshandlinger blant militært personell skal følgende forebyggende tiltak nyttes: informasjonstiltak, ledel sestiltak, miljøtiltak, helsetjenestetiltak og krisetelefontiltak.

M ed bakgrunn i direktivet ble det utviklet en omfattende handlingsplan med innsatsområder innen de nevnte tiltaksområder. Et viktig moment i handlingsplanen er å sørge for at også primærforebyggende tiltak skal kunne brukes. Det ble derfor presisert at selvmordsforebygging skal betraktes som et allment ansvar for hele Forsvarets organisasjon og ikke bare et ansvar for helsepersonell eller andre spesialiserte grupper.

Sanitetsstaben i Forsvarets overkommando var fra starten av en pådriver for å få realisert selvmordsforebyggen de tiltak for Forsvaret. G jennom dette arbeidet ble det synliggjort at hvis en skal lykkes med iverksetting av selvmordsforebyggende tiltak, må hele linjeorganisasjonen med fagpersoner og ulike beslutningsnivå i stabene involveres.

I utgangspunktet er det en formidabel oppgave å sikre de forskjellige mål grupper informasjon og kunnskap om selvmordsforebyggende arbeid i en så stor og kompleks organisasjon som Forsvaret. I 1993 da det første undervisningsprogrammet ble tilpasset, passerte årlig omtrent 21000 vernepliktige gjennom organisasjonen. Det var ca 12000 befal og nesten like mange sivilt ansatte, samt flere tusen FN/N A T O -personell. (M ehlum, 1999)

\section{Opplaering av personell i Forsvaret}

O pplæring omkring selvmordsproblematikk gis i dag gjennom grunnopplæringen til de militære ledere, hvor selvmordsforebygging er et obligatorisk tema. Temaet er ikke et eget fag, men inngår som en naturlig del av opplæringen innen lederskap og personell forvaltning, i krigsskoler, befal sskoler og høyere skoler i Forsvaret. $\mathrm{H}$ elsepersonell og andre nøkkelgrupper som prester, velferdspersonell osv. blir oppdatert gjennom løpende fagseminarer.

\section{Utdanning av vernepliktige}

Vernepliktige soldater fikk gjennom flere år informasjon om selvmordsproblematikk gjennom en standardisert to timers informasjonspakke "Leve livet" som ble utviklet spesielt for å sikre grunnleggende kunnskaper om risikofaktorer og symptomer ved selvmordskriser. U tdanningen ble godt mottatt blant rekruttene.

"Leve livet" ble revidert i 2001. Deler av undervisningsopplegget som man erfarte som hensiktsmessig ble videreført. Blant annet gjaldt dette gjennomføringen som skulle skje troppsvis i grupper på 25-30 soldater, i løpet av de første 3-4 ukene i rekruttperioden.

Det nye undervisningsopplegget "Et rop om hjelp" har også en tidsramme på 2 timer samt et undervisningsopplegg som består av en video, gruppesamtaler $\mathrm{m} /$ veileder og lysark for instruktør. Endringene ligger i en nyprodusert video som inneholder intervjuer og mer tilpasset informasjon om selvmordsproblematikk både generelt og i Forsvaret, samt spesielt i opplegget for gruppesamtalene og instruktørdelen som bygger på en pedagogisk tilnærming som feltprestene har tatt i bruk. M etoden bygger på bevisstgjøring av egne holdninger, kunnskap og verdisyn i forhold til selvmordsproblematikken.

"Et rop om hjelp" ble implementert fra 2002, og det er feltprestene som hittil har hatt ansvaret for undervisningen. U ndervisningsopplegget skal evalueres i løpet av 2005. Det finnes derfor ikke eksakte oversikter over hvordan det har blitt mottatt. Tilbakemel dingene til nå har imidlertid stort sett vært svært positive.

\section{Helsetjenestetiltak}

Forsvarets egen helsetjen este jobber aktivt med selvmordsforebyggende arbeid tilknyttet det militære personell/vernepliktige gjennom bedriftshelsetjeneste, sykestuer, mentalhygienelag med psykolog, psykiater osv. H elsetjenestetil budene vil imidlertid ikke bli utdypet i denne sammenheng. Det bør likevel nevnes at det ovenfor gruppene i Forsvarets internasjonale tjeneste, som er en voksende gruppe, er etablert en rekke støttetiltak. I 1996 ble det blant annet opprettet et eget fagteam (stressmestringsteamet) som består av psykiatere og psykologer som skal sørge for at personellet har fătt den nødvendige kunnskap om forebygging av psykiske stressreaksjoner og hva som kan gjøres om slike symptomer eller reaksjoner likevel oppstår. I denne sammenheng tilbys også i etterkant hjelp til bearbeidelse av eventuelle traumatiske inntrykk og belastninger som personellet kan ha vært utsatt for i tjenesten, og som de ikke har fått bearbeidet nok underveis $i$ tjenesteperioden.

\section{Utdanningsprogrammet Vivat brukt i Forsvaret}

Forsvaret ser også nytten i et mer utfyllende opplæringstilbud i selvmordsforebygging for de tilsatte som i sitt daglige virke arbeider med eller vil kunne komme borti denne type problematikk. Forsvaret inngikk derfor i 2002 et nært samarbeid med utdanningsprogrammet VIVAT.

G jennom et eget instruktørkurs for Forsvarets personell ble det i november 2003 utdannet 20 Vivat-kursledere som skal holde kurset "Førstehjel p ved selvmordsfare" internt i Forsvaret. Instruktørgruppen er spredd over hele landet og satt sammen av personell som har forskjellige roller i det selvmordsforebyggende arbeidet i Forsvaret (prest, sykepleier, psykolog, velferdspersonell, omstillingspersonell osv.). Det har allerede vært gjennomført en del kurs i 2004, og det jobbes aktivt for å få til et bredt tilbud som kan tilbys alle avdelinger som skulle ha behov for dette. De kurs som har vært gjennomført, har vært meget godt mottatt av kursdeltakerne. Forsvarets personell er i stadig bevegelse gjennom beordring, omstilling, rekruttering, avgang osv. Det vil derfor 
være nødvendig å jevnt utdanne nye instruktører som kan tilknyttes de forskjellige geografiske enheter. Dette vil være en utfordring $i$ fremtiden.

\section{Oppsummering}

Det er som kjent generelt vanskeligå måle resultatene av forebyggende arbeid. Selvmordsraten i N orge har gått ned de siste årene. D ette kan ha mange årsaker, og man kan ikke sikkert si hvilke tiltak som evt. har gitt effekt. Det er likevel rimelig å tro at systematisk forebyggende innsats i et større perspektiv, gjennom primær-, sekundær- og tertiærtiltak innarbeidet på et bredt plan i organisasjonen og bevisstgjøring rundt selvmordsforebyggende arbeid vil kunne gi best effekt. Forsvaret har tatt et standpunkt til dette ved å synliggjøre at sel vmordsforebyggende arbeid er et prioritert område i Forsvaret. D et er viktig å arbeide videre med forståelsen av at en ikke må redusere innsatsen selv om man aner bedring. Det kan fort føre til konsekvenser som ikke er ønskelige.

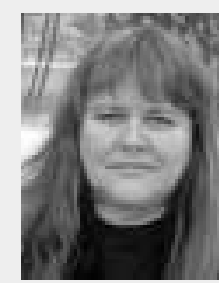

\section{Elisabeth $\mathbf{N}$ æss} er utdannet kommunalkandidat og har mange års erfaring innen personalarbeid og helse, miljø og sikkerhet (H M S) i offentlig sektor. $\mathrm{H}$ un ble ansatt i Forsvarets overkommando,

A rbeidsmiljøkontoret fra 1998, og senere overført til Forsvarsstaben i 2003. Hennes hovedoppgaver er innenfor HM S med spesiell vinkling på rusmidler og selvmordsforebyggende arbeid.

\section{Referanser}

Bull Engelstad, J. C. (1968). Suicides and attempted suicide in $\mathbf{N}$ orwegian $\mathrm{A}$ rmed Forces during peacetime. Military medicine,133, 347-58.

H ytten, K. (1985). Selvmord blant norske soldater1977-84. En retrospektiv studie. Tidsskr N or Lægeforen, 26(105), 1770-3.

M ehlum, L. (1991). Selvmordsforsøk blant norske soldater. En retrospektiv undersøkelse. Tidsskr N or Lægeforen, 5(11),565-8.

M ehlum, L. (formann). (1993). Forebyggelse av selvmord i Forsvaret. U tredning fra Ekspertgruppen for selvmordsforebyggende arbeide i Forsvaret. 0 slo: Forsvarets overkommando.

M ehlum, L. (red.). (1999). Tilbake til livet. Kristiansand: Høyskoleforlaget.

\section{Nye bøker}

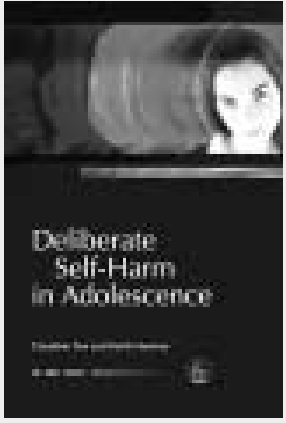

Fox, Claudinel $\mathrm{H}$ awton, Keith. (2004).

\section{D eliberate self-harm in adolescence.}

Jessica Kingsley Publisher. $143 \mathrm{~s}$ ISBN 1-84310-237-4

D ette er en praktisk tilrettelagt bok, beregnet på klinikere. Her blir du oppdatert på alt det nyeste av forskning som har betydning for praksisfeltet. $\mathrm{H}$ er diskuteres risikofaktorer, slike som depresjon, rusmiddelmisbruk og antisosial atferd.

D e viktigste screen inginstrumentene for vurdering av selvmordsrisiko tas opp til kritisk vurdering. Boka gir nyanserte vurderinger av mulige behandlings- og forebyggingstiltak for selvskadende ungdom.

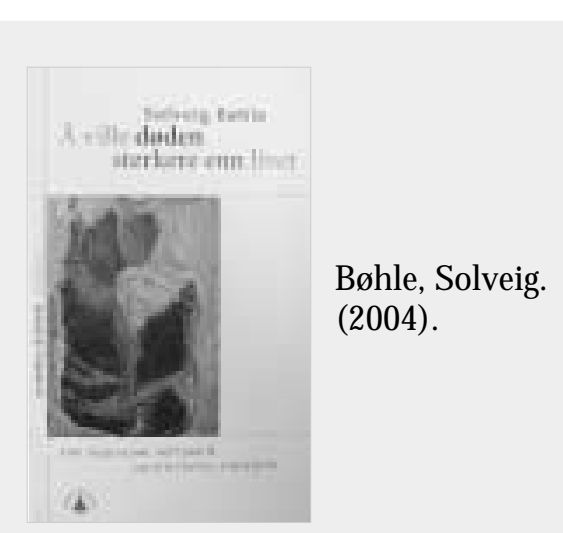

$\AA$ ville døden sterkere enn livet: om depresjon, selvmord og etterlattes situasjon.

O slo: G yldendal akademisk. 181 s. ISBN 82-05-33726-8

( 0 mtales nærmere i neste $n r$.)

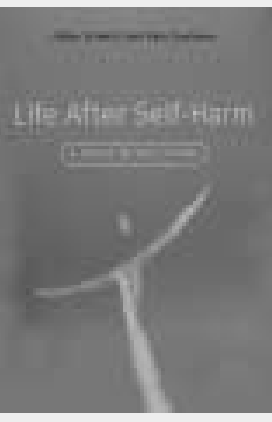

Schmidt, U Irike/ Davidson, Kate. (2004).

Life after self-harm: a guide to the future.

Brunner-R outledge. $109 \mathrm{~s}$. ISBN 1-58391-842-6

Boka henvender seg direkte til klienter som har skadet seg selv enten intensjonen er å dø eller ei.

Den gir trinnvise råd om hvordan klientene kan håndtere kriser, og kan med fordel brukes i samarbeid med en behandler.

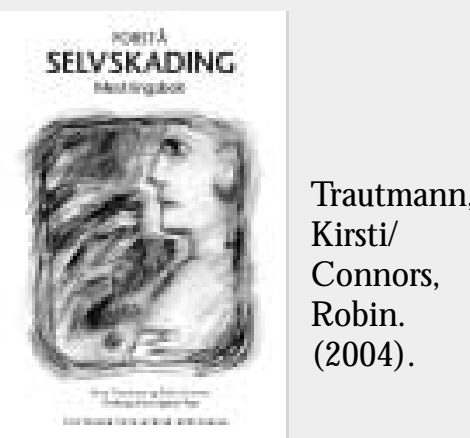

\section{Forstå selvskading:} mestringsbok.

O versatt av Tor Bøe. Rev. utg. Stavanger: Psykiatrisk opplysning. 64 s. ISBN 82-7786-158-3 (Kan bestilles via www.psykopp.no)

D enne arbeidsboka er beregnet på selvskadere, som selv kan bruke den aktivt ved å skrive og tegne i den. O gså fagfolk kan dra nytte av de erfaringer og tanker boka formidler. 